Veaves a vacuum between the index and the rest of the mercury.

Wimpole-street, Aug. 28th, 1894. STEPHEN PAGET.

\section{A FOREIGN BODY IN THE STOMACH.} To the Editors of THE LANCET.

SIRS, - In THE LANCET of to-day there is a very interesting case of a patient on whom gastrotomy was performed for the removal of foreign bodies from the stomach. In the Transactions of the South Indian Branch of the British Medical Association is recorded a very similar case. The patient had swallowed the fastening bolt of his prison door. It was of the usual $L$ shape, being seven inches long and half an inch thick, the short cross-bar being an inch and a half long and pointed. As in the case recorded to-day, so in the Indian case, no injury had apparently been done to the mucous membrane of the gullet. The patient confessed to having $\mathrm{s}$ wallowed the bolt only after he was told that his stools contained iron. The bolt was successfully removed by a gastrotomy performed by Surgeon-Major Mark Robinson, I.M.S., the patient making a good recovery.

$$
\text { I am, Sirs, yours faithfuliy, }
$$

$$
\text { JOHN SMY'H, M.D., }
$$
Surgeon-Major, I.M.S.

Fast India United Service Club, St. James's-square, S.W., Aug. 25th, 1894.

\section{"THE HYDERABAD CHLOROFORM COM- MISSION."}

To the Editors of THE LANCET.

Sins, $-M r$. Arthur H. Ward asserts : ${ }^{\mathrm{I}}$ " It is not possible to feel that, at present, Surgeon-Lientenant-Colonel Lawrie has proved by experiment the truth of his thesis that chloroform is perfectly safe when the respiration alone is watched." This is not my thesis. My thesis is that chloroform is perfectly safe when the inhalation is so conducted that the respiration is not interfered with. I challenge Mr. Ward or anybody else to prove that my proposition - that the administration of chloroform is absolutely safe unless the bieathing is interfered with-has not been confirmed by experiment.

I am, Sirs, rours faithfully,

Edward Lawrie, Surgeon-Lieutenant-Colonel. Hyderabad, Deccan, Aug. 15th, 1894.

\section{ANILINE IN PHTHISIS. \\ To the Elitors of THE LANCET.}

SIRS, - For some months past I have been prescribing the sulphate of aniline to phthisical patients both in private and in hospital practice. About twenty-five years ago Dr. Turnbull of Liverpool administered this drug for the care of chorea. He pointed out how the aniline compound, after a course of $i$ wo or three days, produces a blue tinge of face and ligs; and the study of his reported cases induced me to try the effects of the drug in phthisis on the supposition that it might possibly attack the bacillus in zoco. I have been reticent in speaking of the results runtil I could publish a larger experience, but so far $I$ may at once say that the amelioration of symptoms has been surprising and exceeds my anticipations. My chie object, however, in writing to you is to induce other phy sicians and practitioners who have extended opportunities of treating phthisical patients to prescribe and observe the effects of this remedy. I hope to place my own results before one of the medical societies at some near future date.

I am, Sirs, yours faithfully,

Seymour-street, W., Sept. 1st, 1894. SeyMour TAYLOR, M.D.

\section{STAMMERING AND ITS TREATMENT.}

\section{To the Eiditors of THE LANCET.}

SIRS, - The following suggestions may prove aseful to some of your readers. The perfect ease and fluency with which the worst stammerer I ever encountered could recite long poems first suggested to me, before I commenced my professional studies, the essential elemert in the relief of rhis distressing affection-viz., that the sufferer should have clearly and distinctly formulated in his mind-i.e., should have off by heart what he is going to say before beginning to speak. Each sentence, then, should be completely formed, and should be short, so that this may be more easily done before its utterance is commenced, and the delivery should be slow.. Looking away from the person addressed will he a help, as thereby the mind is more completely centred. Any particular words, the articulation of which is found difificult, should be practised until mastered. Daily reading aloud to himself, or herself, and, when confidence has been sufficiently restored, to others, is also useful. As the complaint is nervous in origin, every means by which the nerves may be strengthened and the general health promoted, such as nervine tonics, sea-bathing, plenty of exercise in pure fresh air, and wholesome and palatable, without being too rich, food should be employed. Alcoholic stimulants and tobacco, if not entirely abstained from, must be very sparingly indulged in, This method has in my hands proved perfectly successful, but the patient must not be discouraged by the improvement being slow at first.

Leeds, Sept. 1st, 1894.

I am, Sirs, yours faitbfully,

Philip Foster, M.D.

\section{A CORRECTION.}

\section{To the Editors of THF LANCET.}

Sirs, - Absence from home has prevented my noticing an error in the reporting of what I said at the meeting of the British Medical Association. During the discussion on perforating ulcer of the stomach ${ }^{1}$ my three cases of operation are stated to have been fatal. As a fact, one patient recovered and $t$ wo died.-I am, Sirs, yours faithfully,

Carlisle, Sept. 4th, 1894 .

RODERICK MACLAREN.

\section{CONSULTANTS' DIFFICULTIES. To the Eators of THE LAxCHr.}

SIRs,-Mrs. M- this morning called upon me with her daughter to consult me about an allment concerning which she had been brought to me in 1889 by Dr. C-. She said she had left his neighbourbcod and was no longer under his care. I declined to attend under any other condition than that of sending my prescription and instractions in the first place to Dr. C C. Mrs. M - - refused to agree to this, and our interview ended. Did I unduly strain the relation of consultant to general practitioner in my endeavour to carry out what I consider to be the right mode of action?

On a recent occasion a gentleman consulted me on the recommendation of his mother's medical adviser, Dr. S-. I gave him a note and prescription to convey to Dr. SA few days later I received a letter from Dr. K- saying that the gentleman, his patient, had brought him my letter to Dr. S- I wrote to him, stating that the patient had come to me through Dr. S-, and that I could only correspond with Dr. S- about him. I afterwards ascertained that Dr. S- had handed my note to the patient to give to his usual attendant, Dr. K- Dr. S- - having no intention of making me a means of transferring another practitioner's patient to himself. I understand that Dr. Krather resents my proceeding, and in order to avoid such untoward resuits I am anxious to elicit from you, Sirs, an opinion as to the best line of conduct to pursue under similar circumstances. In the first case, I bave no doubt lost a patient; in the second, the goodwill of a general practitioner. As one who looks to the profession rather than to the public, I am anxious to bave your guidance in these two cases, which are fairly typical of the difficulties besetting one who strives to act as

Aug. 27th, 1894.

*** We gladly insert the above letter. Would that "Loyal Consultants" were more numerons. The lengths to which some consultants gc-even very bonourable men-in seeing the patients of practitioners whom they know to be both honourable and reasonable men is surprising. The subject is too large and important a one to be dispcsed of in a note to a letter ; but it is one worthy of the attention of both branches of the profession. It is the duty of the consultant in every case to snggest writing to the medical man in actual 